\title{
Maori Economic Development - Te Ohanga Whanaketanga Maori
}

\author{
B.D. PARKER \\ Te Puni Kokiri, P.O. Box 3943, Wellington \\ brett.parker@tpk.govt.nz
}

\section{Introduction}

In 2003 the NZ Institute of Economic Research, in collaboration with Te Puni Kokiri, produced a report entitled Maori Economic Development. This report had the goal of bringing together different strands of analysis in a single overview of the Maori economy, and providing new insights on approaches to Maori development. The objective was to find a way to think about the Maori economy in the same way that we think about the New Zealand, or any other, national economy.

As a result of preparing a series of research papers on different aspects of Maori economic development, the report is able to provide useful insights:

- For Maori, on the things Maori organisations can do to enhance their economic development prospects - in particular, investment in high quality governance is the most critical next stage of development, which must be guided by Maori;

- For New Zealand businesses, on the opportunities available to them to transact with, and invest in, the emerging Maori economy; and

- For the Government, on the broad direction of policies which would enhance Maori economic development. In particular, the government's interest in Maori development is not just about social responsibility or Treaty of Waitangi risk management. Rather, it is a policy area with significant potential to enhance New Zealand's overall economic performance.

\section{The Maori economy}

While the Maori economy is relatively small (as described further), it is significant because of its link to Maori culture. Any useful concept of Maori development must have regard to Maori collective aspirations, including whanaungatanga (kinship), kotahitanga (unity), kaitiakitanga (guardianship) and mana whenua (control of land).

It is difficult to define a 'Maori economy', because Maori interests are not separate from the national economy. For the purposes of the report, the Maori economy is defined as collectively-owned land trusts and incorporations, Maori-owned businesses, and the property owned by Maori households. The wages and salaries earned by Maori workers outside the Maori economy contribute to the wider New Zealand economy.

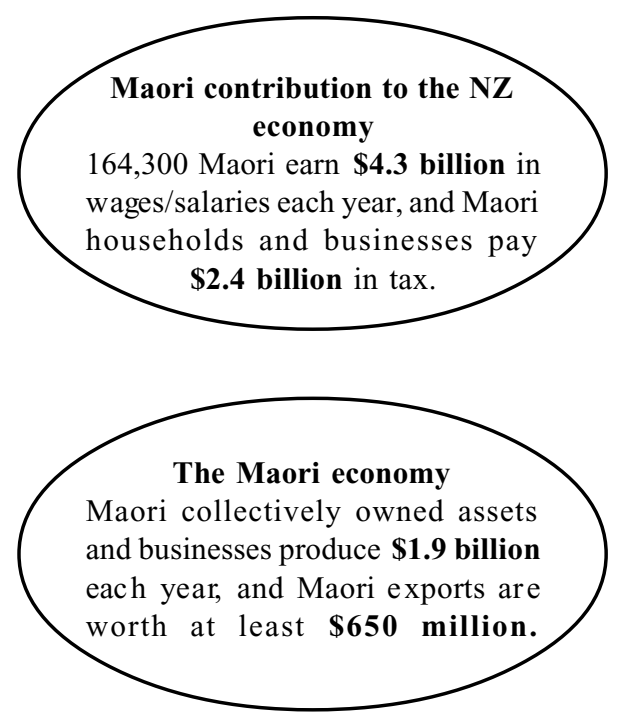

Total Maori production amounts to $\$ 1.9$ billion per year, and Maori production annually contributes 1.4 percent of national value added. While the Maori economy is relatively small, it is also quite profitable, earning about $\$ 826$ million in operating surplus annually or 2 percent of national operating surplus. This is a higher rate of return than that earned by the overall New Zealand economy.

Maori businesses are also net lenders to the rest of New Zealand. This is because Maori land trusts and incorporations retain a greater proportion of their earnings than general New Zealand businesses. The banking sector then re-invests these savings into investment opportunities in the wider economy.

The Maori economy is strongly focused on the industries of farming, fisheries and forestry. As at 2000 it was estimated that $59 \%$ of the Maori commercial asset base was based on agriculture, and another 23\% was based on fisheries and forestry. Maori production is largely based on export-oriented primary commodities and processing. Maori collectively own over 1.5 million hectares of land; however, it has been estimated that 600000 hectares are underdeveloped.

Hence, an improvement in the performance of 
Maori farming businesses is of key importance to Maori economic development. Because Maori own substantial land resources that are not operating near potential, it is important both for Maori development and the performance of New Zealand's farming industries that Maori farms are encouraged to improve their performance.

\section{What does the Maori economy mean for New Zealand?}

The report highlights three primary areas. First, it highlights the importance of the Maori economy by providing evidence of the extent to which it contributes to New Zealand's overall economic wellbeing.

Second, the report illustrates the value of Maori collective ownership. Maori collective ownership is not a 'commercial dead end', but an effective means of safeguarding and growing sustainable assets for the benefit of Maori and the wider economy.

Third, the report highlights potential commercial growth areas within the Maori economy. These include the further development of farming and fisheries assets, and wine, organic produce and horticulture exports. Cultural businesses, such as arts, tourism, and media industries, are also experiencing rapid growth.

\section{The Maori economy is export-focused}

Maori producers are estimated to earn up to $\$ 650$ million in revenue each year from export markets, and about $60 \%$ of Maori commercial assets are reliant on international trade. Maori production currently accounts for about $2.5 \%$ of New Zealand's total merchandise exports.

While the value of Maori production is hard to compare in the same way as other New Zealand industries, the available data indicates that Maoriproduced exports earn more than the overall wine, wool, and kiwifruit industries, and are not far below the value of New Zealand information technology exports. There is some double-counting involved in this comparison, as Maori exports largely consist of fish, beef, sheep meat, wool, and forest products.

\section{Maori employment}

Employment within the New Zealand labour market is a crucial part of Maori economic development. A total of 164300 Maori were in full or part-time paid employment as at March 2001, and between 1996 and 2001 there was a net gain of 8591 jobs for Maori.

Maori households are estimated to earn $\$ 4.3$ billion each year from wages and salaries. This represents nearly $11 \%$ of all wages and salaries received in New Zealand. Maori businesses and households also pay $\$ 2.4$ billion in taxes each year.

It is important to consider the broader implications for New Zealand of the more youthful and fertile Maori population, particularly as Maori are forecast to form a growing proportion of the workforce. For example, Maori are projected to make up nearly $17 \%$ of the total population by 2021 . Consequently, investing in improvements in educational outcomes for Maori will help to raise the overall productivity of the New Zealand labour force.

\section{The road ahead}

Powerful insights and a strong impetus for further development can be gained by considering a Maori economy. This small, but rapidly growing, economy provides a connection between Maori collective aspirations and their economic well-being. This is an economy built around Maori culture, yet highly open to trade with the rest of New Zealand and the rest of the world.

The Maori economy is facing much the same issues as any national economy, and the report shows there is much to be done to ensure that Maori social and economic aspirations are reached. Action needs to be taken by Maori, business and government.

Table 1 New Zealand and Maori exports.

\begin{tabular}{lrr}
\hline Export category & \$ million \\
\hline Wine & (end June 2001) & 198 \\
Information technology & $(2001)$ & 770 \\
Wool & $(1998-99)$ & 285 \\
Kiwifruit & (end June 1998) & 429 \\
Fisheries & (end December 1998) & 1237 \\
Maori-produced exports & $(1999-2000)$ & 650 \\
\hline
\end{tabular}

\section{Maori}

The focus of the report is on Maori institutions, which is a challenge for Maori themselves. There is a critical need to provide leadership that will mould attitudes and behaviour to fit Maori aspirations for higher living standards.

It is also essential to focus on the need to improve the performance of Maori organisations. Effective governance is even more important to Maori organisations than to firms in general, because many Maori organisations are built around permanent ownership of land assets and do not allow free entry and exit of shareholders.

\section{Business}

The report suggests there is room for mainstream 
banks and financial companies to co-operate with Maori organisations to consider establishing a Maori financial institution, which would manage risks in ways appropriate for the Maori economy. This is because the institutions of the Maori economy differ from those prevalent in the rest of New Zealand. More generally, investment in and trade with the growing Maori economy offers numerous opportunities for New Zealand businesses.

\section{Government}

This report proposes a broad agenda for government policy in assisting the development of the Maori economy. This would primarily involve continued investment in improving outcomes for Maori in the labour market.

It suggests Government could also invest more in helping Maori to develop institutional frameworks that would improve governance, and to promote Maori business development. The Government could also modify its own procurement in ways that would deliberately build the capability of Maori organisations. This is already being done in health and education, but could be extended to other areas.

For a copy of the full report "Maori Economic Development Te Ohanga Whanaketang a Maori", please contact: Information Services, Te Puni Kokiri, P O Box 3943, Wellington, email: tpkinfo@tpk.govt.nz,ph: 049226000.

The report and the supporting research papers can also be downloaded from the publications links within the Te Puni Kokiri website: http:// www.tpk.govt.nz 